\title{
BIOGEOGRAPHIC ANALYSIS OF MIDDLE VISEAN ARTICULATE BRACHIOPOD GENERA
}

KELLEY*, Patricia H., National Science Foundation, 1800 G St. NW, Washington, D. C. 20550, U.S.A.; SABLOCK, Peter E., Department of Geology, University of Idaho, Moscow, ID 83843, U.S.A.; RAYMOND, Anne, Department of Geology, Texas A\&M University, College Station, TX 77843-3115 U.S.A.; ISAACSON, Peter E., Department of Geology, University of Idaho, Moscow, ID 83843, U.S.A.

Climate models as well as the distribution and migration patterns of land plants and articulate brachiopods from the Early and Middle Carboniferous suggest that Visean latitudinal temperature gradients were relatively weak, and that the high latitudes may have been warmer than they were during the late Namurian and Westphalian. Biogeographic analysis of middle Visean brachiopod genera from Laurussia and North China supports these conclusions. Cluster analysis, multidimensional scaling and principal components analysis reveal longitudinal differentiation among brachiopod assemblages from Laurussia and the North China plate. Based on their faunal similarity, localities from the east coast of Laurussia (Urals, Moscow Basin, Donets Basin) and North China group together; localities from south central coast of Laurussia (Maritime Canada, England, Ireland and Belgium) group together, and localities from the southwest and west coast of Laurussia (Canada and the United States) group together. On recent Early Carboniferous reconstructions, the east Laurussian localities lie in equatorial, subtropical, and middle latitudes, but exhibit no paleolatitudinal differentiation. This may be the expected result for a biogeographic unit on the east coast of a large paleocontinent during an interval with a well-developed circum-equatorial current. On recent Early Carboniferous reconstructions, all of the localities from south central Laurussia lie near the paleoequator.

West Laurussian assemblages show paleolatitudinal differentiation, which may be the expected result for a biogeographic unit along the west coast of a large paleocontinent influenced by high-latitude westerlies. Within the cluster analysis, assemblages from the Appalachians, Midwest, and Southwest clustered separately from Cordilleran (Idaho, Utah, Montana, Wyoming and Nevada) assemblages. Recent paleogeographic reconstructions for the Early Carboniferous suggest that the Cordilleran localities were paleoequatorial and that the Appalachian, Midwestern and Southwestern localities lay in the southern paleo-subtropical belt. However, the relative diversity of assemblages from these two clusters suggests that the Early Carboniferous paleoequator lay to the south of the Cordilleran localities. Throughout the Early and Middle Carboniferous, individual assemblages within the Appalachian-Midwest-Southwest cluster have higher diversities than individual assemblages within the Cordillera cluster.

We have avoided a hierarchical ranking of these biogeographically distinct groups of assemblages into realms and provinces pending species and community level-analyses of Visean brachiopod communities which are in progress. 